CENDEKIA, Vol. 13. No. 1 April 2019

p-ISSN: 1978-2098; e-ISSN: 2407-8557

Https://soloclcs.org; Email: cendekiaoslo@gmail.com

Center of Language and Cultural Studies, Surakarta, Indonesia

Hambali, IM. 2019. Sinergisme Pendidikan Formal dan Non-formal dalam Pengembangan

Kewirausahaan: Analisis dan Kajian Layanan Bimbingan Karir di Sekolah.

Cendekia, 13(1): 75-86. Htpps://doi.org/10.30957/cendekia.v13i1.250.

\title{
Sinergisme Pendidikan Formal dan Non-Formal dalam Pengembangan Kewirausahaan: Analisis dan Kajian Layanan Bimbingan Karir di Sekolah
}

\author{
IM Hambali \\ Fakultas Ilmu Pendidikan Universitas Negeri Malang, \\ Jalan Semarang 5 Malang \\ Email: im.hambali.fip@um.ac.id
}

\begin{abstract}
Abstrct: Labor issues and unemployment in Indonesia are currently addressed issues to resolve. Entrepreneurship is an important choice to overcome the number of gap between the workforce who have not worked with job opportunities. The purpose of this study is to describe the themes of experience, skills and attitudes that have been and have not been presented in formal schools, and subsequently become the priority themes to be presented in nonformal education. This research was carried out in a descriptive design, exploratory data collected by means of interviews and interviews, and presented it proportionally, analyzed and with technical processes. The conclusions presented in this article include information about the themes of knowledge, skills and attitudes that have not been widely presented in formal schools, and then presented in non-formal institutions in the form of synergism that complement each other.
\end{abstract}

Keywords: entrepreneurship, knowldge theme, skill, attitude.

\section{DOI: doi.org/10.30957/cendekia.v13i1.250}

\section{PENDAHULUAN}

Dilihat dari potensi ketenagakerjaan, Indonesia termasuk negara yang memiliki sumberdaya manusia (SDM) sangat tinggi. Jumlah penduduk sekitar 260 juta, urutan keempat setelah Cina, India dan Amerika, Indonesia termasuk negara padat penduduk. Sementara dilihat dari segi usia penduduk, Indonesia tergolong negara yang banyak memiliki penduduk usia muda (di bawah 30 tahun). Potensi tenaga kerja atau sumberdaya manusia yang tinggi tersebut menjadi sumber pembangunan yang baik.Potensi yang dimiliki menjadi bagian dari aspek yang harus diperhatikan dalam menentukan dalam perencanaan pembangunan secara menyeluruh, termasuk penyiapan melalui kurikulum sekolah formal dan non formal, dimana calon tenaga kerja dilatih dan dididik.Namun demikian, bersarnya jumlah tenaga kerja produktif bukan tanpa permasalahan.

Permasalahan utama ketenagakerjaan di Indonesia mencakup (1) minat kerja yang sering tidak sesuai dengan potensi yang dimiliki, (2) jumlah pencari kerja jauh lebih besar dibanding ketersediaan lapangan pekerjaan, (3) kurang siapnya calon tenaga kerja 
CENDEKIA, Vol. 13. No. 1 April 2019

p-ISSN: 1978-2098; e-ISSN: 2407-8557

Https://soloclcs.org; Email: cendekiaoslo@gmail.com

Center of Language and Cultural Studies, Surakarta, Indonesia

Hambali, IM. 2019. Sinergisme Pendidikan Formal dan Non-formal dalam Pengembangan

Kewirausahaan: Analisis dan Kajian Layanan Bimbingan Karir di Sekolah.

Cendekia, 13(1): 75-86. Htpps://doi.org/10.30957/cendekia.v13i1.250.

yang baru lulus sekolah, yang menyebabkan mereka harus dilatih ulang oleh pihak penyedia dan pengguna tenaga kerja. Persoalan tersebut lebih diperparah apabila calon tenaga kerja atau lulusan sekolah kejuruan memilih menganggur daripada menjalani pekerjaan yang potensinya sebenarnya lebih besar, seperti di bidang pertanian, agrobisnis, dan bidang-bidang produksi yang bersifat industri rumahan (home industry), dll. Perihal yang hampir umum terjadi di beberapa negara adalah minat yang rendah terhadap bisnis pertanian, agro dan kelompoknya. Sementara peluang yang dimiliki sangat besar di bidang tersebut. Siswa tidak banyak (30\% saja) yang memilih bidang agribisnis. Sementara proporsi yang besar dari mereka lebih memilih bidang lain. Dapat diasumsikan bahwa mereka sebenarnya kurang memperoleh informasi yang cukup mengenai agrobisnis tersebut (Smagulova, et.al., 2018).

Data statistik ketenagakerjaan Indonesia angka pengangguran sebenarnya sejak tahun 2013 terjadi penurusan. Tahun 2013 angka pengangguran mencapai 6,2\% dari total tenaga kerja, dan 5,9\% 2014, 6.2\% 2016, 5,6\% 2017 dan 5,1\% di tahun 2018. Angka tersebut menunjukkan menurun daibanding 6 tahun sebelumnya. Angka menganggur di tahun 2006 mencapai 10,3\% dari total tenaga kerja, 9,1\% tahun 2017, 8,4 tahun 2008, 7,9 tahun 2009, 7,1 tahun 2010, dan 2011 menjadi 6,6\% sementara tahun 2012 6,1\% (BPS, 2019). Angka-angka tersebut menunjukkan adanya dinamika fluktuatif namun cenderung tren menurun. Oleh karena itu, daya upaya mengataasi pengangguran harus tetap dijadikan sebagai fokus dan prioritas pemerintah. Solusi utamanya ialah bagaimana problem yang terdapat pada individu calon tenaga kerja dapat diatasi.

Konselor sekolah, dalam hal ini tidak memiliki kompetensi di dalam menyiapkan tenaga kerja dalam arti keterampilan keras. Namun konselor harus memiliki program nyata dalam mengembangkan kepribadian terutama meningkatkan soft skilldari aspekaspek kepribadian yang bersinggungan dengan dunia kerja dan karir. Konselor dapat memberikan layanan maksimal, membuka wawasan dan mind set siswa terkait kenyataan yang ada dalam hub ungannya dengan peluang kerja. Termasuk diantaranya ialah pendidikan kewirausahaan, dan mendorong tumbuh-kembangnya sikap mental yang bersifat produktif dan kreatif. Sementara pendidikan kewirausahaan dapat diterapkan di dalam implementasi kurikulum baik melalui layanan bimbingan oleh konselor, maupun melalui sistem kemitraan oleh trainer (Hambali, 2019). Termasuk soft skill yang harus diperhatikan adalah sebuah metode bagaimana minat siswa yang rendah terhadap kewirausahaan menjadi meningkat.

Kewirausahaan merupakan salah satu bidang yang tidak banyak diminati oleh mayoritas pemuda. Menurut Osakede, Lawanson \& Sobowale (2017) pemuda tidak bergairah memilih dan mengikuti latihan kewirausahaan, dan sebagian besar mereka lebih memilih bidang-bidang yang lebih banyak mengikuti majikan dan bergaji pasti. Tantangan yang besar dan luar biasa akut di Indonesia ialah sedikitnya anak-anak yang mengambil program kewirausahaan. Meskipun demikian, pemerintah, dalam hal ini kementerian tenaga kerja harus mencari jalan dan soulusi bagaimana minat rendah siswa dapat ditingkatkan. Begitu pula konselor sekolah harus mampu menampilkan beberapa even dan sumber-sumber referensi dan data mengenai pentingnya 
CENDEKIA, Vol. 13. No. 1 April 2019

p-ISSN: 1978-2098; e-ISSN: 2407-8557

Https://soloclcs.org; Email: cendekiaoslo@gmail.com

Center of Language and Cultural Studies, Surakarta, Indonesia

Hambali, IM. 2019. Sinergisme Pendidikan Formal dan Non-formal dalam Pengembangan

Kewirausahaan: Analisis dan Kajian Layanan Bimbingan Karir di Sekolah.

Cendekia, 13(1): 75-86. Htpps://doi.org/10.30957/cendekia.v13i1.250.

kewirausahaan. Sementara, ketersediaan SDM berkualitas yang tercermin dalam bentuk keterampilan lunak (soft skill) dan keterampilan keras (hard skill) para siswa sangat menentukan. Katersediaan sumber daya (manusia, alam dan lainnya) tetap menajadi permasalahan dan dimensi tersendiri yang terlepas dari sumber-sumber pengalaman dan referensi informasi (Nguyen, 2017).

Jika dilihat dari komponen yang harus ada dalam pendidikan kewirausahaan memang sangat banyak dan luas. Kelengkapan itu harus dipenuihi agar program pendidikan kewirausahaan dapat berhasil dan efektif. Namaun kelengkapan itu menuntut ketersediaan dana yang cukup dari pihak penyelenggera pendidikan. Meskipun program pendidikan formal dianggap mahal dan memerlukan waktu yang lama, namun keberadaannya tetap menjadi pilihan mayor yang dapat dipertimbangkan. Menurut Øystein Rennemo (2019) menemukan fakta bahwa dalam dialog dan pertukaran pengalaman dalam situasi kelas pendidikan formal dan non folmal sangat mendorong terciptanya saling kepercayaan mereka. Di samping itu juga para pelatih atau guru dari kalangan praktisi dapat menfasilitasi untuk terjadi tindakan usaha nyata, bukan sekedar teori (Rennemo \& Åsvoll, 2019).

Para pemangku kepentingan (stage holder), khususnya dari pemerintah dan lembaga-lembaga sosial kemasyarakatan yang bergerak dalam bidang pemberdayaaan seharusnya memberi perhatian cukup (Gonthier \& Chirita, 2019). Dalam penelitian di Vietnam, Nguyen (2017) menemukan fakta bahwa pemerintah menyediakan program inkubasi kewirausahaan baru. Sekolah-sekolah dan universitas menjadi tempat dan fasilitas yang mampu menawarkan suatu jalur internasional. Itu dilakukan (Hambali, 2019) dalam rangka mempertahankan dan memperkuat ketersediaan pasar dan mempertahankan peluang bahkan penciptaan peluang pasar baru. Oleh karena itu, pendidikan formal dan non formal (pelatihan-pelatihan kerja) menjadi pilihan yang sinergis dan saling melengkapi.

Pendidikan formal adalah pendidikan yang diselenggarakan oleh pemerintah dan masyarakat yang memiliki ciri: (1) kurikulum telah disediakan secara baku dan berjenjang secara menyeluruh, (2) masa belajar berlangsung secara jelas dan berjenjang, (Sekolah dasar, sekolah menengah pertama, sekolaah menengah atas dan perguruan tinggi). Jenjang pendidikan yang ada mencerminkan tingkat kompetensi yang dimiliki oleh para lulusan. Oleh karena itu, dapat dikatakan bahwa pendidikan kewirausahaan melalui pendidikan formal dapat dikatakan memerlukan waktu panjang dan mahal. Namun demikian, ketersediaan waktu bagi siswa yang cukup, untuk mengikuti aktifitas belajar mengajar karena mereka dalam usia sekolah, pendidikan kewirausahaan di sekolah formal dapat menjadi pilihan utama, disamping pendidikan non formal yang dirancang secara padat dan singkat.

Para pakar pendidikan memiliki definisi yang bervariasi mengenai istilah pendidikan formal ini. Seperti Philip H. Coombs mengatakan bahwa setiap kegiatan pendidikan yang dilaksanakan secara sistematis dan teroganisir diluar pendidikan formal adalah termaduk kategori pendidikan non formal. Kegiatan tersebut apat bersifat sendiri-sendiri maupuin dilaksanakan secara bersama, melembaga seperti halnya pendidikan formal. Dengan demikian, ciri utama yang teredapat di pendidikan non 
CENDEKIA, Vol. 13. No. 1 April 2019

p-ISSN: 1978-2098; e-ISSN: 2407-8557

Https://soloclcs.org; Email: cendekiaoslo@gmail.com

Center of Language and Cultural Studies, Surakarta, Indonesia

Hambali, IM. 2019. Sinergisme Pendidikan Formal dan Non-formal dalam Pengembangan

Kewirausahaan: Analisis dan Kajian Layanan Bimbingan Karir di Sekolah.

Cendekia, 13(1): 75-86. Htpps://doi.org/10.30957/cendekia.v13i1.250.

formal ialah: (1) kegiatan itu dilaksanakan diluar pendidikan formal, baik pesertanya anak usia sekolah maupun orang dewasa, (2) penyelenggaranya tidak terbatas apakah perseorangan atau melembaga seperti halnya pendidikan formal pada umumnya, serta (3) memiliki tujuan-tujuan spesifik yang hendak dicapai.

\section{METODE}

Penelitian ini dilaksanakan dengan rancangan deskriptif eksploratif. Fokus utama dan strategi eksplorasi dilakukan dengan memperhatikan langkah "contentAudit". Langkah penelitian yamng dijalani meliputi, (1) mengkaji teori untuk menentukan aspek-aspek yang telah baku dalam pendidikan formal dan noin formal, (2) merumuskan cara dan metode memilih subyek penelitian, (3) menentukan teknik dan instrumen pengumpul data, (4) menentukan jenis teknik analisis data yang digunakan, (5) melaporkan hasil setelah data disimpulkan.

Kajian teori, peneliti melakukan telaah terhadap hasil-hasil penelitian terdahulu terkait dengan tema kewirausahaan. Kesenjangan antara kenyataan dan seharusnya terjadi di masyarakat menjadi salah satu tema pokok dan penting dalam kajian ini. Termasuk dinataranya melakukan kajian awal terhadap permasalahan ketenagakerjaan dan masalah pengangguran. Dari kajian teoritik ini, ditemukan benang merah permasalahan yang terjadi teruma terkait sebab pengangguran dan solusi yang harus diambil.

Subyek penelitian ini ialah Sekolah Menenga Kejuruan (SMK) di kabupaten Pasuruan Jawa Tmur. Jumlah keseluruhan SMK ialah 67. Selanjutnya seluruh jumlah SMK ditetapan 18\% untuk dijadikan sebagai sampel yang diambil secara acak. Jumlah sampel ialah 12 SMK dari 67 SMK (18\%). Data primer diperoleh dengan menemui sumber primer yaitu kepala sekolah, guru, siswa dan konselor sekolah. Selanjutnya, dengan menggunakan instrumen yang telah disiapkan sebelumnya, pengumpulan data dilaksanakan dengan melalui wawancara dan mengisi angket. Hasilnya dianalisis dan disimpulkan secara deskriptif.

\section{HASIL DAN PEMBAHASAN}

\subsection{Deskripsi Data penyajian bidang Pengetahuan, Keterampilan dan Sikap yang diperoleh oleh oleh siswa}

Tabel 1. Pengetahuan yang diperoleh oleh siswa

\begin{tabular}{ll}
\hline MATERI PENGETAHUAN & $\%$ \\
\hline menghimpun dana dari masyarakat & 33,3 \\
menemukan sumber permodalan & 50 \\
menentukan jenis produk yang sesuai pasar & 75 \\
Mencari sumberdaya manusia (tenaga kerja) & 66,7 \\
Mencari calon pelanggan & 41,6 \\
cara memasarkan melalui media online & 58,4 \\
cara melobi calon pembeli & 25 \\
melihat kualitas produk & 66,7 \\
\hline
\end{tabular}


CENDEKIA, Vol. 13. No. 1 April 2019

p-ISSN: 1978-2098; e-ISSN: 2407-8557

Https://soloclcs.org; Email: cendekiaoslo@gmail.com

Center of Language and Cultural Studies, Surakarta, Indonesia

Hambali, IM. 2019. Sinergisme Pendidikan Formal dan Non-formal dalam Pengembangan

Kewirausahaan: Analisis dan Kajian Layanan Bimbingan Karir di Sekolah.

Cendekia, 13(1): 75-86. Htpps://doi.org/10.30957/cendekia.v13i1.250.

\begin{tabular}{ll}
\hline Trik untuk melakukan pembiayaan yang efisien & 41,6 \\
bagaimana menghitung untung dan rugi & 100 \\
\hline
\end{tabular}

\section{PENGETAHUAN YANG DIDAPATKAN OLEH SISWA}

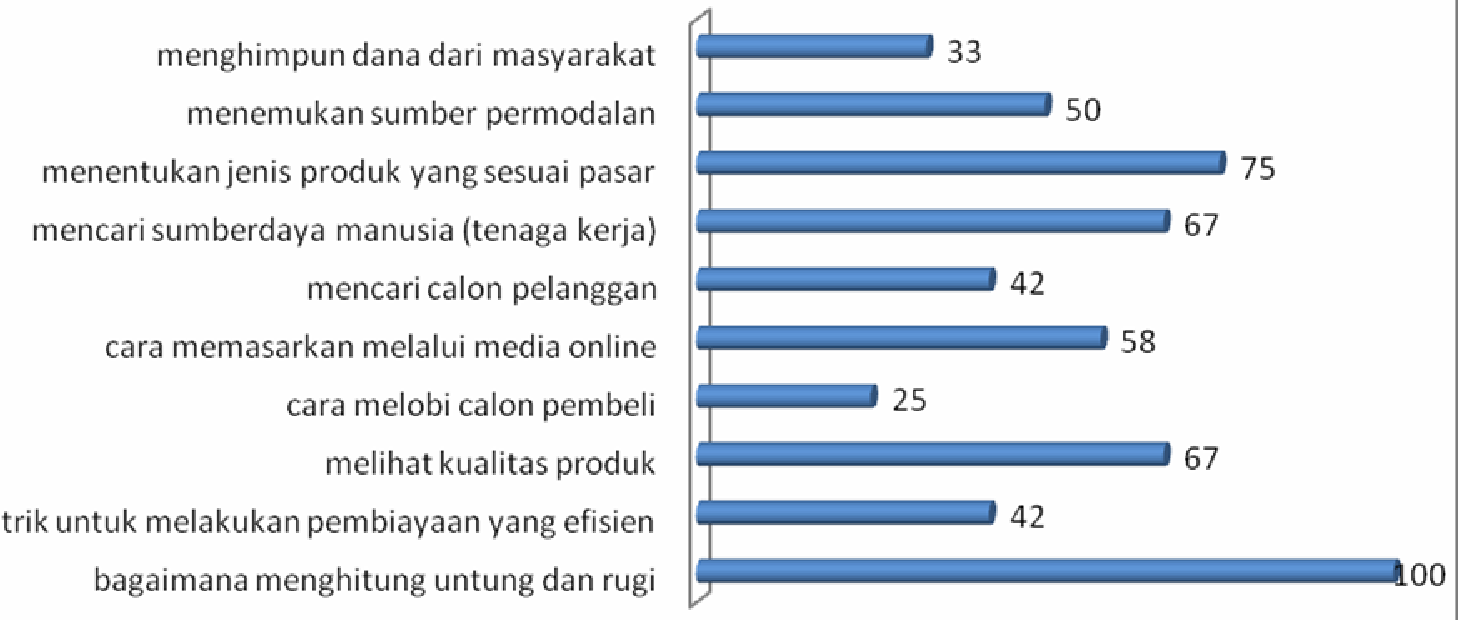

Materi pengetahuan yang diperoleh oleh siswa dari sekolah meliputi materi pengatahuan untuk menentukan jenis produk yang sesuai pasar, materi pengetahuan untuk mencari sumberdaya manusia (tenaga kerja), dan materi pengetahuan tentang bagaimana menghitung untung dan rugi. Materi pengetahuan yang seharusnya diberikan, akan tetapi masih tidak diperoleh siswa dari sekolah adalah materi pengetahuan untuk menghimpun dana dari masyarakat, materi pengetahuan untuk menemukan sumber permodalan, materi pengetahuan untuk mencari calon pelanggan, materi pengetahuan tentang cara memasarkan melalui media online, materi pengetahuan tentang cara melobi calon pembeli, dan materi pengetahuan tentang trik untuk melakukan pembiayaan yang efisien. Materi-materi tersebut tidak diperoleh oleh siswa dari penyajian materi di sekolah sementara pengetahuan tentang hal di atas sangat penting untuk menjadikan siswa sebagai wirausaha baru.

Dari tabel 3 dapat diketahui bahwa ada 4 tema pengetahuan yang yang berlum sepenuhnya diberikan kepada siswa. Empat tema tersebut ialah : (1) cara melobi calon pembeli yang hanya diterapkan di 25\% sekolah sampel, (2) cara mendapatkan dana dari masyarakat diterapkan di 33\% sampel, (3) mencari calon pelanggan diberikan di 42\% sekolah sampel dan trik untuk melakukan pembiayaan yang efisien diberikan di $42 \%$ sampel. Ketiga materi tersebut merupakan materi yang cangat penting untuk memulai sebuah inkubasi usaha baru.

Liku-liku yang harus dikuasi oleh pengusaha baru terkait dengan bagaimana sebuah produk dapat dipasarkan dengan baik. Sumber keberhasilan sebuahinkubasi usaha baru sangat ditentukan oleh bagiaman pemilik usaha mampu menjajakan dagangan ke banyak pihak. Rennemo \& Åsvoll (2019) mengatakan jika ada usaha baru 
CENDEKIA, Vol. 13. No. 1 April 2019

p-ISSN: 1978-2098; e-ISSN: 2407-8557

Https://soloclcs.org; Email: cendekiaoslo@gmail.com

Center of Language and Cultural Studies, Surakarta, Indonesia

Hambali, IM. 2019. Sinergisme Pendidikan Formal dan Non-formal dalam Pengembangan

Kewirausahaan: Analisis dan Kajian Layanan Bimbingan Karir di Sekolah.

Cendekia, 13(1): 75-86. Htpps://doi.org/10.30957/cendekia.v13i1.250.

hendaknya diciptakan situasi yang dapat saling mendukung baik dari pengusaha sendiri, patner kerja, lembaga swasta termasuk kurusus2 dan juga lembaga pemasaran dan keuangan serta permodalan. Jika hal ini dapat terjadi, maka kesulitan memasarkan produk tidak menjadi masalah. Untuk menuju kondisi demikian, maka harus terbentuk diklus kerjasama menyeluruh. Gonthier \& Chirita (2019) menerangkan bahwa pola pikir wirausaha yang ada dalam inkubator dapat didorong dan didayagunakan melalui siklus pembelajaran variasi sumber, seleksi, replikasi dan retensi.

Pengetahuan mengenai dimensi pertumbuhan inkubasi usaha baru tidak lepas dari metode bagaimana pengetahuan itu dapat bersifat melengkapi, tidak terlalu abstrak dan susah diterapkan serta terdapat alur yang jelas dari arah teori makro, teori prosedural, teknis implememntatif dan pelaksanaan di lapangan. Dinamisasi transformasi ilmu, pengalaman dan informasi akan terjadi secara progresif jika dalam proses-proses pertemuan (dalam seting kelas teori dan lapangan praktek) mencerminkan kebebasan berpendapat, dan tidak pengarahan satu arah (Holbert, 2016). Hal demikian dapat terwujud jika antara sekolah formal, dengan tenaga guru dan pendidikan non formal dengan tenaga pelatih dan praktisi dapat saling mengisi.Intinya, pendidikan kewirausahaan harus mengambil pendekatan yang berfokus pada proses untuk mengevaluasi program (Rypestøl, 2017).

Bagaimanapun, menurut Rypestøl (2017), perusahaan dan wirausaha apapun selalu membutuhkan informasi baru, baik peluang, sumber bahan dan beberapa aspek manajemen mutu dan permintaan pasar. Perihal ini, secara teknis, pengusaha harus menemukan jalur-jalur yang dapat mempermudah dan menyempurnakan alur informasi baru tersebut. Oleh karena itu, lembaga pendidikan, formal dan non formal harus dapat mengelola sumber informasi dan pihak terkait menjadi bagian integral. Sedangkan menurut pendapat. Drobyazko (2018) bahwa lembaga non formal, sekolah kejuruan maupun perguruan tinggi dapat dikatakan bermutu apabila mampu merubah kondisi minat yang lemah akut dalam kewirausahaan menjadi cair dan gairah. Ini sangat ditentukan oleh strategi yng dijalaninya, termasuk mengelola informasi menjadi peluang. Ini menjadi pertimbangan jika pengelola lembaga pendidikan hendak merekrut calon guru dan pelatih.

Di sisi lain, menurut Welsha, Tullar, \& Nemati (2016) pendidikan kewirausahaan, baik di kampus-kampus, di lembaga-lembaga kursus maupun di sekolah kejuruan harus mampu menciptakan sikap, menumbuhkan motif, minat, ketabahan (tahan banting), ulet dan tangguh saat menemui kegagalan. Kewirausahaan adalah proses menjadi. Hasil yang dituju bukanlah mengetahui, akan tetapi menjadi. Sulitnya merintis inkubasi bisnis, bahwa keberhasilan tidak selalu di ujung depan, melainkan sering diawali kegagalan dan kegagalan untuk akhirnya menjadi sukses. Lembaga harus dapat menumbuhkan sikap kegigihan agar supaya iaa dapat meneruskan sebuah kegagalan menjadi sebuah kesuksesan, dan meyakini bahwa kegagalan merupakan kesuksesan yang tertunda. 
CENDEKIA, Vol. 13. No. 1 April 2019

p-ISSN: 1978-2098; e-ISSN: 2407-8557

Https://soloclcs.org; Email: cendekiaoslo@gmail.com

Center of Language and Cultural Studies, Surakarta, Indonesia

Hambali, IM. 2019. Sinergisme Pendidikan Formal dan Non-formal dalam Pengembangan

Kewirausahaan: Analisis dan Kajian Layanan Bimbingan Karir di Sekolah.

Cendekia, 13(1): 75-86. Htpps://doi.org/10.30957/cendekia.v13i1.250.

\subsection{Keterampilan Keterlatihanj dan Sikap Siswa}

Temuan keterampilan siswa yang diperoleh selama mengikuti pelatihan di sekolah disajikan pada tabel 2. Adapun sikap siswa disajikan pada tabel 3.

\section{Tabel 2. Keterampilan yang diperoleh oleh siswa}

\begin{tabular}{ll}
\hline MATERI KETERAMPILAN & $\%$ \\
\hline Mendapatkan bahan baku yang murah & 58,4 \\
Menampilkan produk agar menarik & 83,3 \\
Melakukan transaksi melalui media online & 25 \\
Mengurangi resiko & 58,4 \\
Mendapatkan modal dari masyarakat & 0,83 \\
Mendapatkan modal dan perbankan & 41,6 \\
Menetapkan jenis produk yang hendak dihasilkan & 75 \\
Melakukan kegiatan produksi dengan tenaga sendiri & 50 \\
Menjadi sales (petugas pemasaran) & 83,3 \\
Mengelola keuangan perusahaan & 100 \\
Menjalin kemitraan dengan pengusaha lain & 25 \\
Berkomunikasi dengan sesame pengusaha & 50 \\
\hline
\end{tabular}

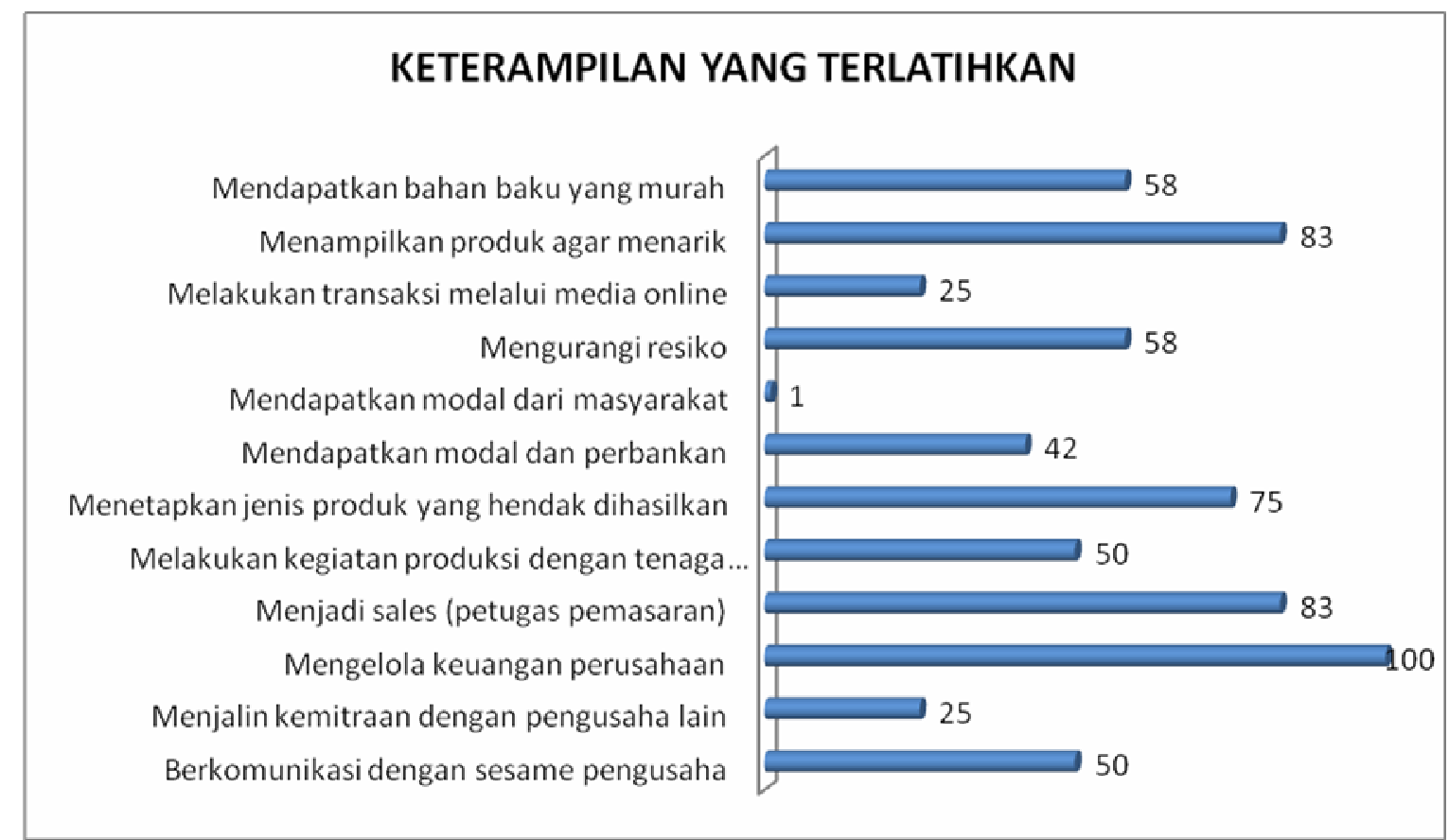

Materi keterampilan yang diperoleh oleh siswa meliputi materi keterampilan menampilkan produk agar menarik, materi keterampilan menetapkan jenis produk yang hendak dihasilkan, materi Keterampilan menjadi sales (petugas pemasaran), materi Keterampilan mengelola keuangan perusahaan. Sementara materi keterampilan yang sebenarnya diperlukan oleh lahirnya home industry meliputi materi keterampilan 
CENDEKIA, Vol. 13. No. 1 April 2019

p-ISSN: 1978-2098; e-ISSN: 2407-8557

Https://soloclcs.org; Email: cendekiaoslo@gmail.com

Center of Language and Cultural Studies, Surakarta, Indonesia

Hambali, IM. 2019. Sinergisme Pendidikan Formal dan Non-formal dalam Pengembangan

Kewirausahaan: Analisis dan Kajian Layanan Bimbingan Karir di Sekolah.

Cendekia, 13(1): 75-86. Htpps://doi.org/10.30957/cendekia.v13i1.250.

mendapatkan bahan baku yang murah, materi keterampilan melakukan transaksi melalui media online, materi keterampilan mengurangi resiko, materi keterampilan mendapatkan modal dari masyarakat, materi keterampilan mendapatkan modal dan perbankan, materi keterampilan melakukan kegiatan produksi dengan tenaga sendiri, materi keterampilan menjalin kemitraan dengan pengusaha lain, materi keterampilan berkomunikasi dengan sesame pengusaha.

Berdasarkan data yang dipaparkan di tabel, diketahui ada 4 tema keterampilan yang masih kurang mendapat perhatian dari sekolah sampel. Tema yang belum mendapat perhatian ialah: (1) mendapatkan modal dari masyarakat $1 \%$, (2) teknis bagaimana melakukan transaksi melalui internet 25\%, dan (3) menjalin kemitraan dalam bewirausaha $25 \%$. Dari data tersebut, sebenarnya masih banyak sisi tema yang masih belum cukup diberikan di sekolah formal. Dalam hal maka pendidikan non formal haru mengambil peran. Keberadaan lembaga pendidikan non formal, kurususkursus sangat membantu untuk melengkapi keterampilan para lulusan sekolah formal. Bagaimana metode yang harus dikembangkan juga pertimbangan yang harus dipersiapkan secara baik.

Rennemo \& Åsvoll (2019) menjelaskan bahwa dimensi pembelajaran melalui dialog dan berlatih harus diperhatikan oleh berbagai pihak. Desain yang dibutuhkan dalam seting pelatihan kewirausahaan harus sudah bergeser dari karakter guru (yang cenderung teoritis) ke sebuah pembelajaran yang berpusat pada siswa dan pengalamannya sendiri untuk dapat membuat refleksi yang merupakan pendekatan pembelajaran yang lebih dari pembelaajran konvensional.

Gonthier \& Chirita (2019) lembaga yang mendirikan inkubator wirausahaan harus dapat meningkatkan sinergi fungsional antara pendiri inkubasi dengan para karyawan maupun anggota yang terlibat. Oleh karena itu, proses-proses pembelajaran dalam seting kelas teori maupun kelas praktek (lapangan) harus memperhatikan dan sekaligus meningkatkan soft skill yang dimiliki oleh masing-masing peserta. Sedangkan Mwasalwiba (2010) menyatakan bahwa pendidikan kewirausahaan harus dilaksanakan secara totalitas. Perihal sumber informasi dan pengalaman menjadi penting untuk menunjang analisis yang komprehensip bagi terwujudnya rencana bisnis yang matang. Holbert (2016) desain pembelajaran yang terbuka, fleksibel, ketersediaan ruang eksplorasi sumber informasi dan peluang serta sumber-sumber kolaborasi merupakan bagian penting dalam pendidikan kewirausahaan.

Tabel 3. Sikap yang diperoleh oleh siswa

\begin{tabular}{ll}
\hline MATERI SIKAP & $\%$ \\
\hline Keberanian mengambil resiko & 91,7 \\
Keberanian menghadapi kemungkinan rugi & 83,3 \\
Tidak malu menawarkan produk & 66,7 \\
Hemat dengan tidak mencampur uang keluarga dengan uang usaha & 91,7 \\
Ulet menghadapi persaingan & 83,3 \\
Tidak putus asa jika produk belum terjual & 100 \\
Keberanian mencoba menawarkan produk ke calon pelanggan & 83,3 \\
\hline
\end{tabular}


CENDEKIA, Vol. 13. No. 1 April 2019

p-ISSN: 1978-2098; e-ISSN: 2407-8557

Https://soloclcs.org; Email: cendekiaoslo@gmail.com

Center of Language and Cultural Studies, Surakarta, Indonesia

Hambali, IM. 2019. Sinergisme Pendidikan Formal dan Non-formal dalam Pengembangan

Kewirausahaan: Analisis dan Kajian Layanan Bimbingan Karir di Sekolah.

Cendekia, 13(1): 75-86. Htpps://doi.org/10.30957/cendekia.v13i1.250.

\begin{tabular}{ll}
\hline Tidak marah saat produk tidak jadi diterima oleh calon pembeli & 75 \\
\hline
\end{tabular}

\section{SIKAP YANG TERTANAMKAN}

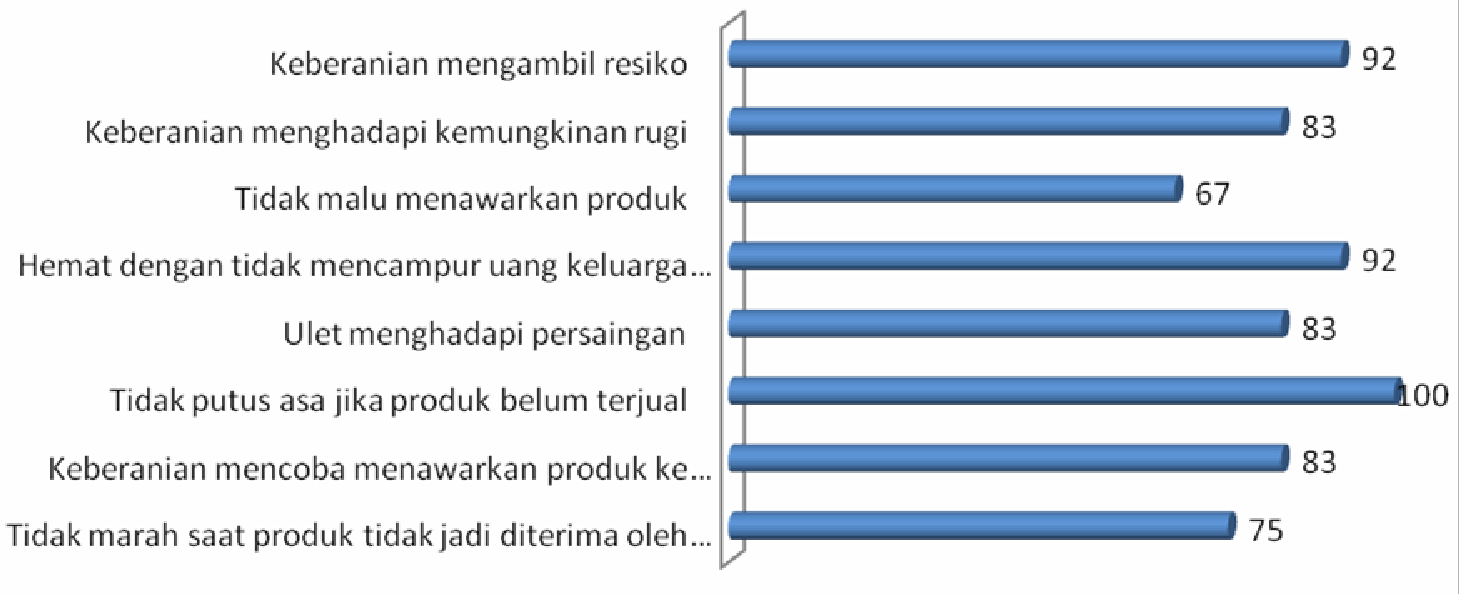

Keberanian mengambil resiko, keberanian menghadapi kemungkinan rugi, Tidak malu menawarkan produk, hemat dengan tidak mencampur uang keluarga dengan uang usaha, ulet menghadapi persaingan, tidak putus asa jika produk belum terjual, keberanian mencoba menawarkan produk ke calon pelanggan, dan tidak marah saat produk tidak jadi diterima oleh calon pembeli merupakan karakter dan sikap mental yang tidak mudah ditanamkan pada diri siswa. Oleh sebab itu, metode, strategi dan model pembelajaran yang diterapkan kepada mereka harus mencakup seluruh ranah dalam kepribadian siswa.

Tabel 3 menunjukkan bahwa sebagian besar sekolah sampel telah menunjukkan perhatian yang besar untuk menanamkam sikap yang ditawarkan oleh peneliti. Dari dimensi sikap yang diajukan, hanya satu hal yang masih perlu dituangkatkan perhatiannya, yaitu bagaimana siswa menjadi pribadi yang sanggup untuk melakukan lobi-lobi dagang melalui proses negosiasi. Potensi dialogis dan bersama yang melekat dalam kebersamaan menghasilkan hasil yang lebih kreatif dan berkelanjutan untuk tantangan kewirausahaan ke depan (Rennemo \& Åsvoll, 2019). Nguyen (2017) juga menjelaskan bahwa sikap positif siswa atau mahasiswa terhadap kewirausahaan dapat ditumbuhkan dengan banyak menampilkan dan mengkomunikasikan sektor kemitraan regional secara lebih gambling. Sementara Osakede, Lawanson \& Sobowale (2017) memplihatkan data yang menunjukkan bahwa norma subyektifitas dan kendali diri sangat berpengaruh terhadap minat siswa dan mahasiswa terhadap pilihan kewirausahaan. Bahkan kenyataan lebih besar siswa dan mahasiswa tidak terlibat dalam kewirausahaan. Kondisi ini dapat diberi makna bahwa minat siswa terhadap kewirausahaan rendah.

Disamping yang disebutkan di atas, untuk menjadikan siswa berkarakter pemberani dan tidak ragu di dalam menjalani wirausaha bartu ialah harus adanya sebuah 
CENDEKIA, Vol. 13. No. 1 April 2019

p-ISSN: 1978-2098; e-ISSN: 2407-8557

Https://soloclcs.org; Email: cendekiaoslo@gmail.com

Center of Language and Cultural Studies, Surakarta, Indonesia

Hambali, IM. 2019. Sinergisme Pendidikan Formal dan Non-formal dalam Pengembangan

Kewirausahaan: Analisis dan Kajian Layanan Bimbingan Karir di Sekolah.

Cendekia, 13(1): 75-86. Htpps://doi.org/10.30957/cendekia.v13i1.250.

metode dan pendekatan yang dapat mendorongan terjadinya perubahan sikap dari negatif menjadi positif. Terjadinya dinamika kelompok yang saling memberi ide baru dan komentar serta wawasan pengalaman. Perlunya sumber berpengalaman atau pelatih dan guru (Rennemo \& Åsvoll, 2019). Ia juga menyebutkan bahwa Khusus dalam seting pendidikan non formal, peserta didik dapat dihadapkan pada permasalahan dan tantangan baru. Dari itu, dinamika pemecahan masalah dan solusi yang akan diambil dapat ditemukan. Di samping itu juga, identifikasi secara cermat dan fisibel mengenai peluang akan terbuka luas. Pendidikan kewirausahaan hendaknya lebih berfokus pada penciptaan peluang, menghasilkan gagasan dari pengusaha tindaklanjutnya. Pemerintah harus lebih giat mempromosikan kewirausahaan untuk mengurangi pengangguran dan itu masuk dalam kurikulum dan tema pembelajaran.

Inkubasi wirausaha baru sebagian besar diawali pada tingkat UKM. Hal ini terjadi akibat sebagian besar calon pengusaha yang baru memulai tidak langsung memiliki permodalan dan jaringan yang luas. UKM memiliki jaringan terbatas, serta kemungkinan bergabuang dengan usaha besar pun juga terbatas. Pembelajaran yang memandirikan sangat dibutuhkan, sementara pengusaha yang sudah kuat hendaknya bias memberi informasi pengalaman tambahan dalam proses pendidikan kewirausahaan (Rennemo \& Åsvoll, 2019). Gonthier \& Chirita (2019) mengemukakan bahwa proses inkubasi merupakan sarana efektif untuk mengumpulkan pengetahuan, pengalaman dan sumberdaya baru. yang pada akhirnya dapat menentukan percepatan dan normalisasi pertumbuhan inkubasi. Orang-orang yang telah "siap" memulai usaha baru akan tidak mudah mendapatkan tenaga kerja baru yang handal melalui rekrutmen.

Persoalan yang menyangkut rekrutmen calon anggota pemberdayaan di bidang informasi maupun kewirausahaan tidaklah sederhana. Motivasi dan komitmen yang bakal terbangun serta aspek semangat kerja merupakan dimensi yang harus diperhatikan. Banyak peserta didik yang berhasil dan sukses menjadi pengusaha setelah mengikuti kursus-kursus, namun tidak sedikit yang gagal. Pengalaman dan informasi maupun peluang yang ditawarkan adalah sama. Perbedaan berada di sisini sumber daya dan kepribadian masing-masing peserta. Akan lebih baik dan efektif jika sebuah inkubasi usaha dipimpin dan dirintis oleh pemilik perusahaan. Meskipun pada akhirnya akan terjadi dinamisaasi plasma atau apapun namanya, namun keberlangsungan proses berkembangnya inkubasi akan bisa terjadi dengan baik, dan itu yang diharapkan (Gonthier \& Chirita, 2019). Jika harapan itu terwujud, maka akan terjadi sinergisme antara wirausahawan satu dengan yang secara simultan dari berbagai tingkatan usahanya. Rypestøl (2017) menjelaskan bahwa sinergisme perusahaan satu dengan lainnya akan mempercepat terjadinya kerjasama simbiosis yang baik. Perusahaan tertentu akan membutuhkan produk dari perusahaan lainnya. Dan siklus akan berlangsung secara simultan. Perusahaan dengan kombinasi inovasi baru secara regional dan niat pertumbuhan tinggi dari pengusaha adalah perusahaan yang berpotensi membentuk jalur industri baru di wilayah tersebut. Ini adalah penting diperhatikan, oleh karenanya, analisis cermat terhadap kebutuhan, potensi dan sumberdaya daerah adalah sangat menentukan bagi percepatan pertumbuhan sebuah inkubasi perusahaan baru. 
CENDEKIA, Vol. 13. No. 1 April 2019

p-ISSN: 1978-2098; e-ISSN: 2407-8557

Https://soloclcs.org; Email: cendekiaoslo@gmail.com

Center of Language and Cultural Studies, Surakarta, Indonesia

Hambali, IM. 2019. Sinergisme Pendidikan Formal dan Non-formal dalam Pengembangan

Kewirausahaan: Analisis dan Kajian Layanan Bimbingan Karir di Sekolah.

Cendekia, 13(1): 75-86. Htpps://doi.org/10.30957/cendekia.v13i1.250.

Rypestøl (2017) juga menyatakan bahwa faktor persaingan antar perusahaan di daerah tertentu memiliki dampak positif, terutama untuk pengamanan harga dan keberlangsungan ketersediaan bahan baku. Khusus industri dan perusahaan baru wajib mengamankan keberlangsungan usaha ke depan dan hal tersebut dapat ditempuh dengan selalu meng_update informasi dan pengetahuan (termasuk teknologi) baru. Bagaimana itu bisa dipersiapkan?

Dari aspek pengetahuan, tema-tema yang belum banyak diperhatikan dalam penyajian layanan bimbingan dan konseling maupun penyajian dalam pembelajaran di sekolah-sekolah formal ialah persoalan pengetahuan yang berhubungan dengan cara memasakan produk atau barang dagangan. Di samping itu juga mengikutsertakan pemilik modal dari masyarakat, serta cara mengatasi masalah produksi dan permodalan. Sementara keterampilan yang masih perlu dilatihkan, namun belum banyak dituangkan dalam pembelajaran di sekolah formal ialah mengatasi sumber keuangan, kemitraan dan pasar serta sikap berani melakukan penawaran dan implikasi pada kesabaran atas ditolaknya penawaran tersebut. Oleh karena itu, beberapa tema yang belum disajikan di sekolah-sekolah formal seharusnya disisipkan di pendidikan-pendidikan non formal melalui pribadi dan kursus-kursus. Komitmen lembaga pendidikan kursus dan pendidikan non formal untuk mengisi kekurangan di sekolah formal adalah merupakan sinergisme yang diharapkan.

\section{SIMPULAN DAN SARAN}

Dari hasil analisis dan penafsiran data di atas, dapat disampaikan kesimpulan sebagai berikut:

Ada tiga tema pengetahuan yang masih belum diperhatikan oleh sebagian besar SMK yaitu keberanian memasarkan dagangan, cara bermitra dengan pihak pemilik dana, dan keberania memasarkan dagangan. Tema-tema keterampilan yang belum banyak disajikan di sekolah formal tema yang belum mendapat perhatian ialahmengatasi permasalahan keuangan dan modal kerja, memperbanyak pelanggan dan bagaimana cara bermitra dengan baik. Keberanian menawarkan dagangan dan produk merupakan bagian tak terpisahkan dari proses pendidikan kewirausahaan. Materi tersebut belum banyak ditanamkan di sekolah formal.

Setelah diketahui beberapa kekurangan pendidikan formal dalam memberikan tema-tema penting dalam layanan bimbingan karir seperti halnya disampaikan pada keismpulan 1,2 dan 3 maka seharusnya lembaga pendidikan non formal hendaknya mencermati tema-tema yang belum banyak disajikan di sekolah-sekolah formal, untuk selanjutnya mendapat perhatian di lembaga pendidikan formal.

\section{DAFTAR RUJUKAN}

Drobyazko, S.I. et al. (2018). Quality Improvement of Higher Education As A Factor of Intellectual Capital Development, Academy of Entrepreneurship Journal .Vol: 24 Issue: 4.

Fayolle, A.From Craft to Science: Teaching models and learning processes in entrepreneurship education. Journal Of European Industrial Training, Volume 32, Issue 7. 
CENDEKIA, Vol. 13. No. 1 April 2019

p-ISSN: 1978-2098; e-ISSN: 2407-8557

Https://soloclcs.org; Email: cendekiaoslo@gmail.com

Center of Language and Cultural Studies, Surakarta, Indonesia

Hambali, IM. 2019. Sinergisme Pendidikan Formal dan Non-formal dalam Pengembangan

Kewirausahaan: Analisis dan Kajian Layanan Bimbingan Karir di Sekolah.

Cendekia, 13(1): 75-86. Htpps://doi.org/10.30957/cendekia.v13i1.250.

Gonthier, J. \& Chirita, G. M. (2019) .The role of corporate incubators as invigorators of innovation capabilities in parent companies.Journal of Innovation and Entrepreneurship. A Systems View Across Time and Space 8:8. https://doi.org/10.1186/s13731-019-0104-0.

Hambali,I. (2019). Examining the Relevance of Indonesian Vocational High School Career Outcomes to the Labor Market, Journal of Social Science Education Research. Vol.10. no. 1 133-155.

Holbert, N. (2016)., (2016) The powerful ideas of making: building beyond the curriculum. Journal of Innovation and Entrepreneurship A Systems View Across Time and Space 5:30. https://doi.org/10.1186/s13731-016-0058-4.

Linton, G. \& Markus Klinton. (2019) University entrepreneurship education: a design thinking approach to learning.Journal of Innovation and Entrepreneurship.https://doi.org/10.1186/s13731-018-0098-z.

Rennemo, Q. (2019) Existential learning: dialogues and places to be(come) in entrepreneurial Ba practice. Journal of Innovation and Entrepreneurship.https://doi.org/10.1186/s13731019-0103-1.

Mwasalwiba, E.S. \& Ernest Samwel. (2010). Entrepreneurship education: a review of its objectives, teaching methods, and impact indicators. Education and trainingvolume 52 , issue 1 .

Nguyen, C. (2017). Entrepreneurial intention of international business students in Viet Nam: a survey of the country joining the Trans-Pacific Partnership. Journal of Innovation and Entrepreneurship. A Systems View Across Time and Space 6:7. https://doi.org/10.1186/s13731-017-0066-z.

Olaniran, S.O. \& Dumsani Wilfred Mncube. (2018). Barriers To Effective Youth Entrepreneurship And Vocational Education. Academy of Entrepreneurship Journal. Vol: 24 Issue: 4.

Osakede, U.A., Lawanson \& Sobowale, D.A. (2017). Entrepreneurial interest and academic performance in Nigeria: evidence from undergraduate students in the University of Ibadan. Journal of Innovation and Entrepreneurship A Systems View Across Time and Space 6:19. https://doi.org/10.1186/s13731-017-0079-7.

Rennemo, Q \& Åsvoll H. (2019). Existential learning: dialogues and places to be(come) in entrepreneurial Ba practice. Journal of Innovation and Entrepreneurship A Systems View Across Time and Space20198:9. https://doi.org/10.1186/s13731-019-0103-1

Rypestøl , J.O. (2017).Regional industrial path development: The role of new entrepreneurial firms. Journal of Innovation and Entrepreneurship A Systems View Across Time and Space 6:3. https://doi.org/10.1186/s13731-017-0064-1.

Santafe-Rojas, A-K, Laura Teresa Tuta Ramírez \& Neida Albornoz-Arias. (2018). Prospective Analysis and Influence of Social Entrepreneurship in Development In Catatumbo, Norte De Santander, Colombia. Academy of Entrepreneurship Journal. Vol: 24 Issue: 4.

Smagulova, S. et al. (2018). Entrepreneurship and Investment Environment In the Central Asian Transition Countries: Case Kazakhstan. Academy of Entrepreneurship Journal. Vol: 24 Issue: 4.

Welsha, D.H.B., Tullar, W.L.\& Nemati, H.(2016). Entrepreneurship education: Process, method, or both?. Journal of innovation \& knowledge 1 (2016), 125-132. 